logos_i_ethos_2016_(43)_numer_specjalny_2, s. 213-228

DOI: http://dx.doi.org/10.15633/lie.1970

\title{
Елена Твердислова
}

\section{Чаадаев и Печерин: одно время - две креативные эпохи}

Общество - это сумасшедший дом, которым управляют его пациенты.

(Э. Гофман)

Петр Чаадаев (1794-1856) и Владимир Печерин (1807$1885)$ - властители умов своего поколения, оставили в его сознании след, сродни, говоря словами Осипа Мандельштама, «алмаза по стеклу», хоть и были вполне Елена Твердислова - переводчик с польского (сочинений Иоанна Павла II, Р. Ингардена, о. Ю. Тишнера, К. Михальского, Т. Оболевич), автор статей и книг по литературоведению и философии, поэт, прозаик. Живет в Израиле. Email: helenatverd@gmail.com. «частные лица» ${ }^{1}$. Обратиться к сопоставлению этих столь ярких фигур на небосклоне русской словесности в широком смысле побудила меня работа польского профессора Анджея Валицкого - ему первому принадлежит опыт их сравнения в ракурсе истории идей ${ }^{2}$. Было бы крайне важно с учетом этого знания рассмотреть судьбы Чаадаева и Печерина также и в общественно-литературном контексте.

1 О. Э. Мандельштам, Петр Чаадаев, в: О. Э. Мандельштам, Собрание сочинений в 4 mm., т. 2, Москва 1991, с. 284.

2 А. Валицкий, Россия, католичество и польский вопрос, пер. Е. Твердисловой, Москва 2012, с. 623. 
Прототипы пушкинского Онегина - Чаадаев, на что указал сам автор («Второй Чадаев, мой Евгений» ${ }^{3}$ ), и лермонтовского Печорина («Герой нашего времени») - скрытую за ним фамилию Печерина не трудно угадать, - действительно проложили две борозды, по которым отныне потащат любое инакомыслие в России: психушка и эмиграция (в том числе принудительная). Более того, почти современники, они между тем обозначили две, креативно разные, эпохи: пушкинскую и лермонтовскую. Одна питалась упованием, другая - едва ли не инфернальная, и у каждой свой опыт, который распространялся на всю последующую историю России почти что параллельно. Крупнейшие инакомыслящие в России Чаадаев прославился своей оппозиционностью, Печерин - диссидентством. Этот водораздел представляется самым принципиальным, ибо оппозиция и диссидентство в России как понятия до конца не проанализированы, нередко они подменяются, их даже путают, тогда как они имеют свои четко обозначенные смыслы и особенности, свою маркеровку. Оппозиция пытается с властью договориться, войти с ней в контакт, объяснить свое положение. Диссидентство рвет всякие связи и уходит в подполье - видимое или невидимое, не обязательно в эмиграцию, которая может быть оппозицией, как например, Герцен. Но главное - для диссидентства нет и не может быть никаких контактов с властью, взаимопонимание исключено, договориться нельзя.

Строго говоря, первым русским диссидентом и в этом смысле предшественником Печерина стал князь Андрей Курбский, наместник Ивана Грозного.

Перейдя к польскому королю, получив от него крупные вассальные пожалования, Курбский не просто вошел в среду литовско-русской знати, нередко «отъезжавшей» из Москвы в Вильно и обратно. Он захотел обосновать свой отъезд и обратился к Ивану IV с посланием, в котором обвинял царя

3 А. Пушкин, Евгений Онегин. Роман в стихах, в: А. Пушкин, Полное собрание сочинений в 10 mm., т. 5, Ленинград 1978, с. 17. 
в неслыханных гонениях против воевод, покоривших Руси «прегордые царства» ${ }^{4}$.

Но не только в этом заключены расхождения Чаадаева и Печерина. Всё сложнее и разностильнее. Чаадаев, не выходя из потенциального диалога с властью, позволил себя втянуть в ловушку, и как сокол на царской охоте, попал в нее именно потому, что пытался вести с властью разговор: иногда скрытый, иногда открытый, подразумеваемый или предполагаемый, тогда как он не имеет тарифа. Игра действительно стоила свеч, да еще каких! Говоря современным языком, Чаадаев действовал по схеме фрейма, следуя определенной когнитивной модели, но он не осознавал, что лодка, в которую сел и поплыл, приведет его не к искомому берегу, а к неведомому концу. В ответ на официальную версию «умалишенного» ${ }^{5}$ Чаадаев в 1837 году пишет Апологию сумасшедмего ${ }^{6}$, демонстрируя строгую логику, нарративную четкость, безусловную эрудицию, украшая повествование блестящим слогом, показывая и доказывая ложность того, что было определено в отношении него «безумием». Как ни странно, он верил в здравый смысл и полагался на него. Кто только в России не играл в сумасшедших, озорнее всего, но и трагичнее это удавалось Гоголю, который мастерски расправлялся с ними. Не случайно Чаадаев ссылается, не называя впрямую, на Ревизора. Апологией Чаадаев узаконит кликуху.

Бывший офицер, закален в сражениях, завсегдатай светских салонов, Чайльд Гарольд, западник, член масонских лож, тайных обществ, любимец женского пола... Что только за Чаадаевым не числилось! Но прилепает католик - слишком не похож на своих, даже внешним видом. Тем же тавро спустя почти полвека пометят

4 Переписка Ивана Грозного с Андреем Курбским, ред. И. С. Лурье, Ю. Д. Рыков, Москва 1981, с. 5. Оставим в стороне спор о подлинности самих писем. Факт бегства Курбского от царя неоспорим.

5 М. О. Гершензон, Чаадаев, Москва 2000, с. 142.

6 П. Я. Чаадаев, Апология сумасшедшего, в: П. Я. Чаадаев, Полное собрание сочинений и избранные письма, т. 1, Москва 1991, с. 523-538. 
другого католика - Владимира Соловьева, за ересь провозглашения объединительных идей в лоне Единой Церкви. Самый легкий способ выделить чужака из стаи: и того и другого голословно. По сей день прибегают к доказательствам, чтобы правду сделать правдой: оба были похоронены по православному обряду с причащением и отпеванием. Нашелся ли в России заступник за Чаадаева? Такой же открытый и недвусмысленный - каким было его собственное поведение? Герцен - из своего далека? Пушкин - в завуалированной форме? Но влияние он оказал огромное, конкретное и бесспорное - прежде всего на князя И. Гагарина, который, навсегда покинув Россию, пошел намного дальше, смело шагнув за пределы страны и от всего отказавшийся, во имя «светлого церковного будущего». В чем-то его путь схож с печеринским, однако Печерина никто не соблазнял, и его дорога была драматично самостоятельна.

Что значит быть сумасшедшим в России? Когда-то всё высказывать позволялось скоморохам - им одним, и никто их за это не казнил. Постепенно маркёры поменялись. Если раньше скоморох говорил о том, что видит и слышит, и это сходило ему с рук, то со временем озвученная крамола, неугодная властям, превратилась в клеймо. На скомороха нашлась гильотина. Ему стали давать по рукам. Припечатанное Николаем I «смесь дерзкой бессмыслицы, достойной умалишенного» ${ }^{7},-$ по поводу первого Философического письма Чаадаева, определило судьбу мыслителя. Спорить можно с чем угодно и как угодно, но не по вопросам сумасшествия, тут ни у кого никаких прав не было: ни у судей, ни у профессоров, ни у богатых и знатных, ни у образованных. Психушка как смирительная рубаха для всякого инакомыслия, нередко чисто субъективного,

7 Ср. неопубликованное документальное свидетельство М. А. Дмитриева, которое приводит А. А. Штейнберг. «Николай I [...] смотрел неблагоприятно на литераторов, как на людей мыслящих, следовательно опасных деспотизму... Понятие о просвещении не отделялось в его голове от мысли о бунте; а бунтом почитал он всякую мысль, противную деспотизму...». А. А. Штейнберг, Пушкин и Е. Д. Панова, с. 45, http://feb-web.ru/feb/pushkin/serial/ v68/v68-045-.htm. 
обнаружила свои возможности раз и навсегда. (Впоследствии к ней примкнул алкоголизм, и за примером ходить не надо: тень его по сей день лежит на В. Высоцком и В. Ерофееве - на вскидку). Индивидуальность мысли не всегда поддается пониманию, да еще немедленно, но замечается она, как правило, скорее и чаще, чем сама мысль.

Высказывания Чаадаева высоко ценились современниками, его «письма» ходили по рукам, их содержание интеллектуальной элите Москвы и Петербурга было хорошо ведомо. Но за публикацией Писем, оформленных как невинная переписка с некоей адресаткой (что было чистой правдой), скрывалась не менее драматичная судьба его корреспондентки, такое же злонамеренное, но по другой причине, обвинение в умопомешательстве. Беспроигрышная лотерея.

Вот тут мы впрямую и в чистом виде сталкиваемся с тем, что социолог чикагской школы Эрвинг Гофман определил фреймом: спектакль в спектакле, история в истории, шкатулка в шкатулке . $^{8}$

Однако, если относительно Чаадаева клеймо стало таковым, ибо упало из уст царя, то в отношении адресатки Е. Д. Пановой оно носило субъективный характер. Тут старался муж, лично заинтересованный в том, чтобы больную поместили в лечебницу, - завладеть ее имуществом. Интрига сжить со свету добрую знакомую Чаадаева, таинственным образом совпавшая с развернутой властями кампанией засадить его под домашний арест, нашла свою мышеловку. То, каким негодяем был муж Пановой и его личное участие в «дрязгах» против жены, доказано письмом Е. Д. Пановой Чаадаеву, где ею изложена и собственная семейная драма 9 (от которой Чаадаев,

8 Э. Гофман, Представление себя другим в повседневной жизни, пер. А. Д. Ковалева, Москва 2000, с. 304.

9 А. А. Штейнберг, исследуя подробно линию Чаадаев - Панова, приводит неопубликованное свидетельство М. А. Дмитриева. «Первое письмо, - записывал Дмитриев, - особенно замечательно: в нем было много горькой правды, сказанной резко, но метко и красноречиво, хоть и не всегда верно». См. М. А. Дмитрие, Воспоминания, Рукописное отделение Всесоюзной государственной библиотеки им. Ленина, шифр М. 8184/2, с. 338-339. Полностью 
разумеется, отстранился, но это отдельно). Есть большое искушение не просто сравнить письмо Пановой - открытое, искреннее, чистосердечное, просящее поддержки, с тем, какое своему избраннику посылала Татьяна Ларина, чуть ли не посчитать и само общение Чаадаева со своей соседкой встречей пушкинских героев, великий соблазн усиливается еще и тем, что на Чаадаева как прототипа своего героя прямо указывал автор, однако такое допущение не просто натяжка, а и передергивание фактов, ибо корреспонденция Чаадаева и Пановой берет свое начало несколькими годами позже уже означенной «отповеди». Другое дело - Панова была не единственной такого рода адресаткой Чаадаева, интерес которого к ней, однако, был далеко не случайным, хоть и не лишенным прозаичности: ее муж одолжил у Чаадаева немалую сумму денег. Между тем ум соседки по имению, ее начитанность, образованность, смелость суждений и радикальность взглядов не могли не привлекать к ней людей мыслящих, вот и Пушкин внимательно следит за перипетиями ее жизни, шифруя ее «католичкой», ибо известно, что она сочувствовала польским повстанцам. Но - и это вполне естественно - в письмах Чаадаеву она не договаривала о своем муже, не чуравшемся писать доносы ${ }^{10}$. «Последовавшие события показали, что имя и судьба Пановой оказались тесно связанными с Философическими письмами. Слова Жихарева (одного из биографов Чаадаева - Е. Т.), что Панова была в стороне от следствия, требуют коррективов. 17 декабря 1836 г. Московское губернское правление освидетельствовало умственные способности Екатерины

с оригинальным французским текстом письмо приводится в статье: А. А. Штейнберг, Пушкин и Е. Д. Панова, ор. cit., с. 45-55.

10 А. А. Штейнберг приводит и другие свидетельства М. А. Дмитриева: «Москва наполнилась шпионами. Все промотавшиеся купеческие сынки; вся бродячая дрянь, неспособная к трудам службы; весь обор человеческого общества подвигнулся отыскивать добро и зло, загребая с двух сторон деньги: и от жандармов за шпионство, и от честных людей, угрожая доносом... О некоторых проходили слухи, что они принадлежат к тайной полиции. Я знал двоих из таких лиц...». И на полях Воспоминаний Дмитриев записывает имена: сенатора Нечаева и... Василия Максимовича Панова. См. М. А. Дмитриев, Воспоминания, Рукописное отделение Всесоюзной государственной библиотеки им. Ленина, шифр М. 8184/2, с. 211. 
Дмитриевны Пановой по просьбе ее мужа и определило считать ее сумасшедшей и поместить в лечебное заведение» ${ }^{11}$.

История Екатерины Дмитриевны Пановой, урожденной Улыбышевой, настолько мрачная, запутанная и изгаженная вмешательством конкретных людей, показавших подлость без границ, что тут система «высоких» моральных принципов, провозглашаемая автором Философических писем, невольно отступает на задний план, а попросту говоря, дает сбой. К сожалению «версию о сумасшествии Пановой поддержал и сам Чаадаев в письменных объяснениях московскому обер-полицеймейстеру Л. М. Цынскому; [...] Достаточно пострадав, Чаадаев стремился убедить власти, что не разделяет мнения “ныне бредствующих умствователей” ${ }^{12}$. А между тем Гершензон однозначно пишет, что «если читатель, имея под рукою “Философические письма” Чаадаева, даст себе труд пробежать эти оба письма параллельно, он убедится, что чаадаевское представляет собой не только прямой ответ на письмо Пановой, но в некоторых частях даже и не может быть понято без последнего» ${ }^{13}$.

Тут самым трагическим образом перекрещиваются две, я бы определила их как постановочные, линии: семейная, личная, сугубо утилитарная, возникшая по явно корыстному поводу, - Пановой; и государственная, мировоззренческого масштаба и с очевидно устрашительным механизмом воздействия - Чаадаева. По странному стечению обстоятельств оба участника по схоже сфабрикованному делу оказались исполнителями одной креативной модели «театра сумасшедшего действия». Для оправдания Чаадаева надо заметить, что запущенный механизм был настолько отлажен, что его заступничество за Панову ей нисколько не помогло бы. И если цель оправдывает средства, то цель г-на Панова была достигнута самым легким путем - по шпалам, проложенным гонителями Чаадаева. При

11 М. Лемке, Николаевские жандармы и литература (1826-1855), Санкт-Петербург 1908, с. 448-449. Цит. по: А. А. Штейнберг, Пушкин и Е. Д. Панова, ор. сіt., с. 50.

12 А. А. Штейнберг, Пушкин и Е. Д. Панова, ор. cit., с. 49-50.

13 М. О. Гершензон, Чаадаев, ор. cit., с. 71. 
разных исходных данных им пытаются вынести схожий вердикт. Игра идет большая, но по одним правилам. И тень от помешанной соседки ложится на репутацию Чаадаева, который и так уже интеллектуально, да и морально опорочен, тем более, что Панова оказалась потенциальной сторонницей и даже выразительницей его взглядов. «Почему пробуждение религиозного чувства принесло ей не мир и светлую радость, а грусть, томление, почти угрызения совести?», - задается вопросом Гершензон, а ведь Чаадаев, замечает он, «пишет так, как пишут к близкому человеку письмо на жгучую тему» ${ }^{14}$. Она доискивалась истины, Чаадаев эту истину ей открыл и ее обнародовал ${ }^{15}$.

Более того, благодаря ей он, возможно, нашел для себя и наиболее соответствующий ему жанр - излагать историософские взгляды в эпистолярной форме. Но это - теория, а на практике упечь Панову в психушку и признать слабоумной вышло легко и просто. «После официального объявления Чаадаева сумасшедшим Панов активизировал свою деятельность; оно давало своего рода прецедент и, быть может, подсказало Панову способ избавиться от жены, удовлетворив при этом свои корыстные расчеты» ${ }^{16}$. «Вызывающее поведение» Чаадаева ${ }^{17}$ порождало сплетню, она «стала казенной легендой», которая вошла в моду, замечает А. Лебедев ${ }^{18}$. Судьба Пановой, с одной стороны, явилась производным от чаадаевской, с другой - ее окончательно разрешившимся вариантом: в ее случае обвинение в потере разума узаконилось сумасшедшим домом, и собственная ее неприязнь к жизни, какую питала, наблюдая, сопротивление мужу, откровенному негодяю, служившему системе и отсюда получавшему все возможные для себя выгоды, лишь усугубили ее

14 М. О. Гершензон, Чаадаев, ор. cit., с. 72-73.

15 «Письмо разбило лед после 14 декабря» - точный отклик Герцена в Письмах из Франции и Италии, в: А. И. Герцен, Собрание сочинений в 9-ти тm., т. 3, Москва 1956, с. 468.

16 А. А. Штейнберг, Пушкин и Е. Д. Панова, ор. cit., с. 51.

17 А. Лебедев, Чаадаев, Москва 1965, с. 17.

18 А. Лебедев, Чаадаев, ор. сіt., с. 18. 
трагическую развязку. Мышеловка, поставленная на Чаадаева, сработала на ней. Но одна развязка не породила вторую.

«Умывая руки», отстраняясь от судьбы Пановой, Чаадаев нисколько этим не облегчал ни участи Пановой, ни своей собственной, и без того она уже была предрешена. Но своим личным участием во всей этой истории он невольно «помогал» власти вырабатывать методику борьбы с инакомыслием. Его последующее письмо царю лишь усиливало и без того изощренные способы манипулирования «душевной болезнью», которые станут в советский период едва ли не ведущими средствами подавления эстетических свобод и оригинальности мышления.

Любопытен в этом смысле рассказ Куприна Ошибка (обвиненный в помешательстве ради шутки становится, в итоге, таковым): проще всего в России удавалось обвинить в безумии - не в краже, плагиате, даже убийстве - все они требовали обоснований. Безумие получило картбланш. История Чаадаева и Пановой становится свидетельством «заурядности», «обычности» судебного оговора. Не окажись Л. Толстой «еретиком» в глазах Синода, его ждала бы участь сумасшедшего.

Если Чаадаев символизировал собой пушкинскую эпоху («Товарищ, верь...»), со всей присущей ей надеждой и верой в дружбу («Вниманье дружбы возлюбя»), служением Отечеству, патриотизмом, то лермонтовскую - с характерным для нее отчаянием, скептицизмом и безысходностью (герои Лермонтова либо сами убийцы, либо их убивают) выразил Владимир Печерин ${ }^{19}$. А потому отъезд Чаадаева за границу (еще до Писем), который, кстати, спас его от неминуемого наказания за участие в тайных кружках, не превратился в бегство, теплится надежда - неясная, расплывчатая. И он возвращается - неожиданно для декабристов. Друг Чаадаева И. Д. Якушкин, уверенный, что тот уехал навсегда, показал на него при допросе. Однако Чаадаев, не порывая с Родиной, продолжал

19 Автобиограбия В. С. Печерина, в: Русские пропилеи, т. 1: Материаль по истории русской мысли и литературы, ред. М. Гершензон, Москва 1915, с. 94-157. 
искать пути для диалога с властью, не приняв во внимание, какой угрозой могли стать для него самого его Философические письма. В чем-то он оставался идеалистом, который верил, что общество можно спасти интеллектуально, исправить Россию Европой, развитой христианской цивилизацией.

Кстати, Философическое письмо выходит в 1836 году и именно в этом году Печерин принимает окончательное решение - становится невозвращенцем. Его отъезд за границу куда радикальней. Это был в полном смысле сумасшедший поступок: образованный и интеллигентный дворянин со знанием древних и восточных языков, обещающей карьерой на престижной кафедре Московского университета от всего отказывается, всё покидает и уходит в никуда, мотивируя это тремя причинами: «Религия» («Идти говеть по указу и причащаться Св. таин без веры и с кощунством? До этого я не мог унизиться: мне это казалось первою подлостию и началом всех прочих подлостей» ${ }^{20}$ ). «Профессорство» («Профессорство в России невозможно... Может быть в Петербурге я мог бы ужиться как-нибудь; но разгульная Москва с ее вечными обедами, пирушками, вечеринками и беспрестанною болтовнею вовсе не шла к тому строгому и грустному настроению, с каким я возвращался из заграницы» $\left.{ }^{21}\right)$. «Литература» («Я очень хорошо понимал, что в тогдашней России, где невозможно было ни говорить, ни писать, ни мыслить, где даже высшего разряда умы чахли и неминуемо гибли под нестерпимым гнетом, уж не Чаадаева ли имел он в виду? - в тогдашней России, с моей долей способностей я далеко бы не ушел. Я скоро бы исписался и сделался бы мелким пошленьким писателем со всеми его низкими слабостями» ${ }^{22}$ ). Его настроения нашли выражение в знаменитом стихотворении «Как сладостно отчизну ненавидеть...». Не исключено, что Лермонтов не только избрал Печерина прототипом своего героя, но и вступил с ним в невидимую полемику,

20 Автобиография В. С. Печерина, ор. сіt., с. 100.

21 Автобиограбия В. С. Печерина, ор. сit., с. 100-101.

22 Автобиограбия В. С. Печерина, ор. сit., с. 101. 
откликнувшись на это стихотворение своим: «Люблю Отчизну я, но странною любовью»...

В некотором роде Печерин был Чаадаеву прямая противоположность. Он в одиночку пытался решать онтологические проблемы, наощупь двигаясь путем личных религиозных исканий, перед которыми остановился Чаадаев, даже отрицал их. Насквозь интеллектуал, Петр Яковлевич не проверял на себе способы познания мира изнутри, вообще любая практическая сторона жизни была ему чужда. Будучи «западником», он высоко поднял статус Бога, а вместе с этим Истории как провидения и обозначил роль Церкви в развитии всего человечества. «Пронзительное описание русской обособленности - одна из существенно важных черт во взглядах Чаадаева на Россию», - подчеркивает А. Валицкий ${ }^{23}$, замечая, что эти мысли были близки целому поколению русской интеллигенции, которая болезненно воспринимала свою обособленность, «обозначенную в литературе определением “бедные люди” ${ }^{24}$.

Печерина Валицкий считал «типичным представителем» «бедных людей», предпослав ему определение «конвертанта Николаевской эпохи» ${ }^{25}$. Отказавшись от России как образа жизни и мысли, Печерин остался в памяти России едва ли не единственным доказательством активности «малого дела», которое под силу таким вот «бедным людям». По собственному утверждению, он был «монах из Дублина» ${ }^{26}$; «эмигрантом на все времена» (ПервухинаКамышникова) ${ }^{27}$ и вместе с тем «персонажем русской культуры» $(\text { Е. Г. Местергази })^{28}$. «Дон Кихотом независимости» нарек Печерина

23 А. Валицкий, Россия, католичество и польский вопрос, ор. cit., с. 57.

24 A. Walicki, $W$ kręgu konserwatywnej utopii. Struktura i przemiany rosyjskiego słowianofilstwa, Warszawa 1964, c. 271-291.

25 А. Валицкий, Россия, католичество и польский вопрос, ор. cit., с. 57.

26 См. В. С. Печерин, Apologia pro vita теа. Жизнь и приключения русского католика, рассказанная им самим, ред. С. Л. Чернов, Санкт-Петербург 2011.

27 См. Н. М. Первухина-Камышникова, В. С. Печерин: Эмигрант на все времена, Москва 2006.

28 Е. Г. Местергази, В. С. Печерин как персонаж русской культуры, Москва 2013, c. 296. 
друг и хранитель его архива Ф. Чижов, «мечтатель» и «горячая голова» - характеристика Гершензона. Сам же Печерин придумал себе, отчасти конспирируясь, псевдоним (для Автобиографии, писем) «г-н Фуссгангер», то есть пешеход, а буквально бродяжка - с немецкого Fussgänger, еще точнее и остроумнее - доктор Фуссгангер ${ }^{29}$.

Его линия судьбы со всем им написанным была более извилистой, хотя и не столь изощренной. Не стоит забывать, что он сам был хозяином своего положения, но оно зависело не только от него самого, но отчасти от людей, с которыми его сводил случай. Публикуя впервые в «Русских пропилеях» Автобиографию Печерина, М. Гершензон, который собрал и подготовил к печати все материалы этого номера журнала, коснулся драматичной истории рукописи, прямо-таки мистической. Он ее восстановил по письмам Ф. Чижова, подлинники которых сопровождали саму рукопись, как и приложенные к ней письма Печерина Чижову. Весь «портфель» Чижов отправил (в 1877 году) тогдашнему редактору журнала «Вестник Европы» М. М. Стасюлевичу, но тот, повидимому в ожидании продолжения, задержался с публикацией. Вскоре Чижов умер (в том же году), и рукопись осталась в редакции «Вестника Европы» до смерти М. М. Стасюлевича (в 1911 году, хотя редакцию журнала он покинул после 1908 года). Лишь в 1915 году Автобиография увидела свет, в отрывках, в «Пропилеях» ${ }^{30}$, с предисловиями Гершензона и Чижова.

Гершензон, коротко характеризуя «горькую жизнь» Печерина, писал:

Он был строгий ученый, глубокий знаток своего предмета, и вместе страстная, поэтическая натура. Его опьянила мечта о «лучшем мире», об освобождении человека для прекрасной и радостной жизни... ${ }^{31}$.

29 Автобиография В. С. Печерина, ор. сіt., с. 98.

30 Автобиография В. С. Печерина, ор. сіt., с. 94.

31 Автобиография В. С. Печерина, ор. сіt., с. 95-97. 
Говоря о его заграничном бытии и вояжах, он отмечает его мытарства, безденежье и разочарования - как в социалистических идеях, обернувшихся чистой утопией, так и в людях. В 1840 году, ошеломив своих друзей в России, он перешел в католичество, вступив в один из самых суровых монашеских орденов - редемптористов (св. Искупителя). Спустя двадцать лет, под влиянием нового переворота, порвал с монашеством и ушел из Ордена в священники. И все эти годы его не покидала тоска по России.

Университетский товарищ доктора Фуссгангера Ф. Чижов замечает:

Я со своей стороны считаю долгом уверить читателей, что в повествовании о своей бродяжнической жизни г. Фуссгангер ничего не преувеличил, ничего не прикрасил и что весь рассказ его есть сущая правда. Олицетворенная беспечность, Дон Кихот независимости, он, оставив отечество без особой цели, без предварительного намерения оставить его навсегда, вдруг очутился на чужбине без гроша в кармане, то есть решительно без всяких средств к существованию, без связей не только дружеских, а даже и приятельских, без надежд, без планов, без ожиданий, отданный под покровительство одной звезды. На нее как-то он издавна возлагал все свое упование, и тоже никогда не отдавши себе отчета: почему, отчего и на каком основании. Сам он никак и никогда не хотел согласиться, что вся его жизнь была бесцельна, безнамеренна и беспланна ${ }^{32}$.

И словно споря с ним, в письме к нему Печерин отвечает:

Ты думаешь, что я оставил Россию так просто, очертя голову, без всякого плана? Ты ошибаешься. Все было обдумано, взвешено и рассчитано до последней копейки ${ }^{33}$.

Разумеется, Печерин не был столь знаменит в России, как Чаадаев, но за границей он пользовался заметным влиянием и его, уче-

32 Автобиография В. С. Печерина, ор. cit., с. 98-99.

33 Автобиограбия В. С. Печерина, ор. сіt., с. 100. 
ного, даже приглашали служить в Ватикан. Прославился он в качестве оратора и проповедника. Круг близких ему людей, в итоге, стал настолько узким, что казалось, вряд ли кто его запомнит, и все же он запечатлен в благодарной памяти единоверцев, прежде всего И. Гагарина (П. Пирлинг), и, конечно, Герценом в Былом и думах, где, однако, портрет Печерина субъективен и неточен.

В целом чаадаевская оппозиционность была сродни декабристской при всем неприятии им самого восстания, когда после его провала его участники дружно кинулись высказывать свои претензии царю, веря в его благоразумие. Первоначально разделяя некоторые воззрения декабристов, Чаадаев не разделил их поступка. Печерин искал в каждой идее возможность доказать ее справедливость на деле. Как ни парадоксально, но одну из универсальных и обобщающих идей Чаадаева об «обособленности» русского народа как отрицательной черте России и ее истории стремился по-своему преодолеть Печерин, испытывая на себе угнетавшую его «изолированность». Он всеми силами желал проверить теоретические идеи республиканцев, ища в жизни их «практический смысл», который не нашел на Родине. И всё же оба эту особенность не смогли преодолеть.

После подавления восстания декабристов «отрицательный механизм» в России сосредоточил свои действия исключительно на интеллектуальном уровне. В случае Чаадаева и Печерина он сработал и социально: исключением из общественной жизни, одного - путем домашнего ареста, другой сам выбрал себе достойную «изоляцию» в качестве капеллана в ирландской больнице, где он прослужил последние почти двадцать пять лет. Между тем Чаадаев и Печерин определили в общественно-художественном сознании России на долгие годы ее креативный облик: пушкинский и лермонтовский. Причем Печерин в какой-то степени рисовал себя наследником Ленского:

Как сын пустыни, я терпеть не мог оседлости. Усесться на профессорской кафедре, завестись хозяйством, жениться, быть Коллежским Советником и но- 
сить Анну на шее, - все это казалось мне в высшей степени комическим. Как Ленский в Онегине, я тоже «носил бы стеганый халат» и пр. и пр. и пр. ${ }^{34}$.

Более позитивный пушкинский тип показал свою склонность к оппозиционности, тогда как тяготеющий к негативной оценке лермонтовский тип - к диссидентству, которому чужд компромисс. Оба направления в истории России оказались живучими, и краски их выражения по сей день напрямую зависят от характера власти.

\section{Библиография}

Автобиограбия В. С. Печерина, в: Русские пропилеи, т. 1: Материалы по истории русской мысли и литературы, ред. М. Гершензон, Москва 1915, с. 94-157.

Валицкий А., Россия, католичество и польский вопрос, пер. Е. Твердисловой, Москва 2012.

Герцен А. И., Письма из Франции и Италии, в: А. И. Герцен, Собрание сочинений в 9-ти ттт., т. 3, Москва 1956.

Гершензон М. О., Чаадаев, Москва 2000.

Гофман Э., Представление себя другим в повседневной жизни, пер. А. Д. Ковалева, Москва 2000.

Дмитриев М. А., Воспоминания, Рукописное отделение Всесоюзной государственной библиотеки им. Ленина, шифр М. 8184/2.

Лебедев А., Чаадаев, Москва 1965.

Мандельштам О. Э., Петр Чаадаев, в: О. Э. Мандельштам, Собрание сочинений в 4 тm., т. 2, Москва 1991.

Местергази Е. Г., В. С. Печерин как персонаж русской культуры, Москва 2013.

Первухина-Камышникова Н. М., В. С. Печерин: Эмигрант на все времена, Москва 2006.

Переписка Ивана Грозного с Андреем Курбским, ред. И. С. Лурье, Ю. Д. Рыков, Москва 1981.

34 Автобиография В. С. Печерина, ор. сіt., с. 101. 
Печерин В. С., Apologia pro vita теа. Жизнь и приключения русского католика, рассказанная им самим, ред. С. Л. Чернов, Санкт-Петербург 2011.

Пушкин А., Евгений Онегин, Роман в стихах, в: А. Пушкин, Полное собрание сочинений в 10 mm., т. 5, Ленинград 1978, с. 5-164.

Чаадаев П. Я., Апология сумастедшего, в: П. Я. Чаадаев, Полное собрание сочинений и избранные письма, т. 1, Москва 1991, с. 523-538.

Штейнберг А. А., Пушкин и Е. Д. Панова, http://feb-web.ru/feb/pushkin/serial/v68/ v68-045-.htm.

Walicki A., W kręgu konserwatywnej utopii. Struktura i przemiany rosyjskiego słowianofilstwa, Warszawa 1964. 